\title{
OPTIMIZATION OF DOSES AND TIME \\ OF MINERAL NITROGEN APPLICATION \\ ON WINTER WHEAT PLANTINGS
}

\section{Onychko Viktor ${ }^{1}$ Onychko Tetiana ${ }^{2}$}

DOI: https://doi.org/10.30525/978-9934-571-89-3_102

Grain is of primary importance in supplying the growing number of world population with food, that's why increasing of its production is very significant in many countries. Grain is the main energy source of vital activity of human body. Grain and leguminous crops takes $76 \%$ in the structure of foodstuffs [4, p. 7]. Today there are considerable differences between its production and consumption in developing and developed countries. In future the need for grain will not be filled due to the urbanization (for example today $45 \%$ of people live in cities, but in 2020 their part will rise to 60\%) and improvement of the well-being in the developing countries [5, p. 14]. Winter wheat takes the main place between grain crops. It is cultivated all over the world and is one of the main foodstuffs for nearly $35 \%$ of world population. It provides the population with about $20 \%$ of energy requirements. Winter wheat is one of the main products of world trade.

Under the conditions of north-east forest steppe of Ukraine winter wheat is one of the leading grain crops. But yielding capacity and gross collections of its grain are unstable by years of its cultivation. Prospects of grain crops cultivation are based on improvement of intensive technologies in the sphere of resource saving. We need to ensure the conditions for the development of every separate plant starting from the selection of predecessor, fertilizers, sort and finishing with harvesting. Only in such conditions we can get better realization of genetically valuable characteristics of modern sort resources of winter wheat [3, p. 4].

There are not secondary agro-technical measures in the cultivation technology. To get a high yield of wheat grain you need to do all required works qualitatively and in due time. If you don't do at least one of these works it can lead to decrease of yielding capacity in spite of all your efforts. You should constantly control growth and development of plants directing their power to the formation of necessary structural elements of yield [4, p. 10-11].

Grain crops and wheat in particular need minerals together with other factors of environment (light, warmth, moisture) to have normal growth, development and ripening. Minerals take part in metabolism and formation of organic weight and yield. That's why in order to get high and stable yields of high quality it is significant to select suitable fertilizer. It is especially important for wheat to apply the appropriate doses in optimal time filling the need of plantings in nutrients [5, p. 289].

\footnotetext{
${ }^{1}$ Sumy National Agrarian University, Ukraine

${ }^{2}$ Sumy National Agrarian University, Ukraine 
One of the main nutritive elements for wheat is nitrogen. Wheat belongs to nitrogen-loving plants. To form $1 \mathrm{~kg}$ of grain we need $3,75 \mathrm{~kg}$ of nitrogen. During the vegetation period of plants the consumption intensity of nitrate and ammoniacal nitrogen forms is various. The thing is that at the beginning of vegetation the content of carbohydrates of active forms in winter wheat which are necessary for ammonia fixation and protein production is quite low. At later stages of wheat development fructose content in leaves is higher which leads to increasing of ammonium nitrogen uptake [6, p. 10-14].

In Ukraine average amount of applied mineral fertilizers is $30 \mathrm{~kg}$ per ha which is much fewer comparing with the USA, Canada, India and the Argentine. Beside insufficient number of applied fertilizers there is quite low effectiveness of nitrogen using in households. For example if we apply $1 \mathrm{~kg}$ of nitrogen then grain yield is more on $12-13 \mathrm{~kg}$ only whereas the same index in France is $20 \mathrm{~kg}$, in Germany $20,3 \mathrm{~kg}$. Such a big difference in efficiency of nitrogen using is connected with imperfect schemes of nitrogenous nutrition [6, p. 10-14].

So, by constant price increase for fertilizers in order to get maximal yield growth of winter wheat we should originate the scheme of nitrogenous nutrition which would correspond with physiological needs of a crop in certain soil and climatic conditions.

The researches were conducted in grain and hoed crop rotation of Sumy National Agrarian University. The soil, where our researches were conducted, is typical lowhumic black soil. The predecessor of winter wheat was soybean for grain. Agricultural methods of growing were common for conditions of climatic zone. The researches were conducted by the scheme of simple experiment. Crop acreage of lots was $50 \mathrm{~m}^{2}$, accounting area was $25 \mathrm{~m}^{2}$, frequency - four-time which corresponds with the demands for conducting experiments with grain crops. Rotation of variants in replication was sequential. As an object of the researches we selected the sort Dostatok. Field experiments were done according to generally accepted methods [1, p. 25-120; 2, p. 5-10].

The main criteria as for the rise of grain productivity of winter crops due to the application of nitrogen fertilizers is considerable increase (on 100-200 pieces per $\mathrm{m}^{2}$ and more) of productive plant stand density (to 556 pieces per $\mathrm{m}^{2}$ in 2016 , to 738 pieces per $\mathrm{m}^{2}$ in 2017 and 770 pieces per $\mathrm{m}^{2}$ in 2018). Nitrogen fertilizers application in autumn as an extra nutrition and on frozen soil favoured to the rise of general tilling capacity index: in $2016-1,8-2,0$, in $2017-2,0-2,1$, in $2018-2,2-2,8$.

As a result of positive influence of mineral nitrogen application we determined sufficient increase of winter wheat yielding capacity (Figure 1). Herewith the increase of grain yield varied from 0,14 to 0,62 ton per ha.

The main factors which influenced the efficiency of extra nutrition by nitrogen fertilizers were the time frames of its application and doses. The highest yielding capacity of grain on the average during the years of researches was achieved by autumn dosing in the phase of wheat tillering with the dose $\mathrm{N}_{30-} 0,65$ ton per ha and similar to it three-time dosing by common norm $\mathrm{N}_{60}$ (ground $+\mathrm{N}_{15}$ on frozen soil + $\mathrm{N}_{30}$ - stem elongation $+\mathrm{N}_{15}$ - ear formation) - 0,64 ton per ha. On other variants of the researches the doses by $\mathrm{N}_{30}$ and $\mathrm{N}_{60}$ on frozen ground and in the phase of stem 
elongation ensured fast similar levels of yield. The dosing by the same norms in the phase of ear formation led to the decrease of yielding capacity in comparison with other variants.

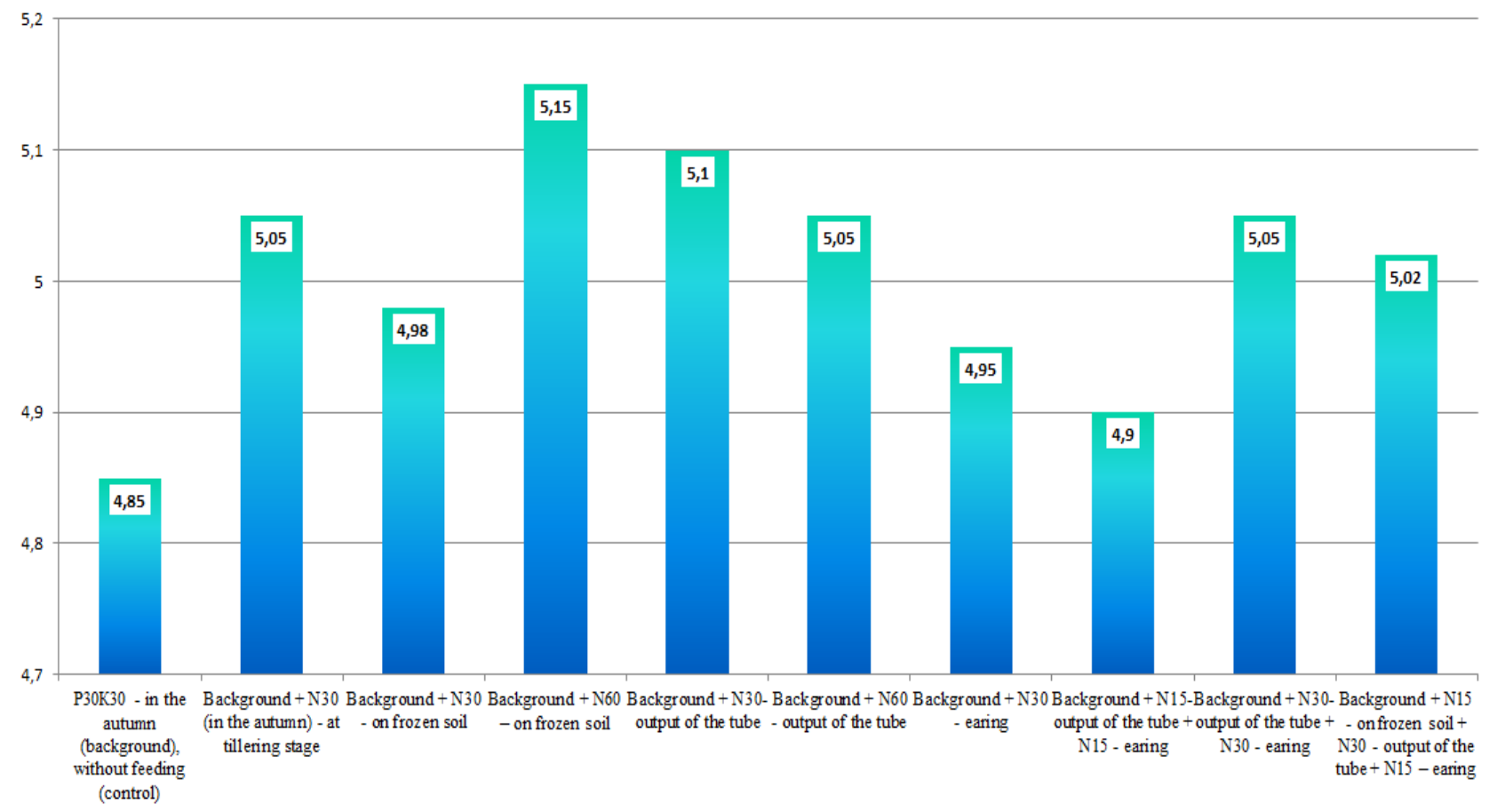

\section{Figure 1. The influence of doses and time of nitrogen fertilizers application on yielding capacity of winter wheat grain, 2016-2018}

On the average during the years of researches the most effective dose as for the payback of mineral fertilizers was the dose $30 \mathrm{~kg}$ per ha of nitrogen primary nutrient which were applied as autumn fertilization. In this case $1 \mathrm{~kg}$ of nitrogen primary nutrient applied with fertilizers ensured additionally $20,6 \mathrm{~kg}$ of winter wheat grain. This variant gave the maximal yield during the years of researches $-5,05-8,25$ ton per ha.

In such a way growing winter wheat using minimal doses of main fertilizer, autumn fertilization of planting by dose $\mathrm{N}_{30}$ favoured to significant increase of yielding capacity of grain and growth of payback of applied fertilizers.

\section{References:}

1. Dospekhov B. A. (1985). Metodika polevogo opyta (s osnovami statisticheskoy obrabotki rezul'tatov issledovaniy) [Methods of field experience (with the basics of statistical processing of research results)]. Moskva: Agropromizdat. (in Russian)

2. Instytut zemlerobstva UAAN (2001). Metodychni vkazivky shhodo provedennja poljovykh doslidzhenj i vyvchennja tekhnologhiji vyroshhuvannja zernovykh kuljtur [Methodical for the design of field operations and cultivation of grain crops ]. Čabany. (in Ukrainian).

3. Kyryčenko V. V. (2010). Specialna selekcija i nasinnyctvo polovyx kultur: navčalnyj posibnyk [Special selection and seed production of field crops: study guide]. Xarkiv : IR im. V.Ja. Jurjeva NAAN Ukrajiny.

4. Lyxochvor V. V., Petrynenko V. F., Ivashhuk P. V. (2008). Zernovyrobnycztvo [Grain production]. Lviv: Ukrainski tekhnolohii. (in Ukrainian). 
5. Shpaar D. (2012). Zernovye kul'tury : vyrashchivanie, uborka, khranenie i ispol'zovanie [Crops: growing, harvesting, storage and use]. Kiev : izdatel'skiy dom "Zerno". (in Ukrainian).

6. Xodanyczkyj V., Xodanyczkaya O. (2016). Azot yak baza formuvannya vrozhayu ozymyny [Nitrogen as a base for winter crop production]. Agribusiness today, vol. 11, no. 115, pp. 10-14. Retrieved from: http://agro-business.com.ua/agro/ahronomiia-sohodni/item/713-azot-iak-bazaformuvannia-vrozhaiu-ozymyny.html. 